\title{
Academic Supervision of the State Principal School (Evaluative Study in Rejang Lebong Regency, Indonesia)
}

\author{
Haimah \\ Universitas Prof. DR. Hazairin, SH Bengkulu \\ haimahmpd@gmail.com
}

Bambang Sahono

Universitas Bengkulu

bsahono@unib.ac.id

\author{
Manap Somantri \\ Universitas Bengkulu \\ manap@unib.ac.id \\ Connie \\ Universitas Bengkulu \\ connie@unib.ac.id
}

\begin{abstract}
This study aims to evaluate the academic supervision program of the principal of a public elementary school in Rejang Lebong Regency, Indonesia. This research is an evaluation study of the CIPP model with a qualitative approach. The subjects of this study were principals and teachers of public elementary schools in Rejang Lebong Regency. Techniques for data collection include observation, interviews, and documentation, as well as data reduction, data presentation, and verification. The outcomes of the study reveal that, first; the setting of the principal's academic supervision program does not meet the criteria. There are still numerous flaws, such as the principal's lack of understanding of the notion of academic supervision, which has prevented them from properly developing program planning. Second, the input of the academic supervision program has not fully supported the program; there are still many shortcomings such as no stakeholder support, and not being able to find the right strategy both in planning and in program implementation. Third, the process of the academic supervision program has not been following the plan, such as the program implementation steps. Fourth, the product of the academic supervision program has not shown an increase in teacher performance. However, both teachers and principals want the principal's academic supervision program to continue by correcting all its shortcomings and weaknesses. The conclusion of the academic supervision program of the principal of the public elementary school in Rejang Lebong Regency as a whole has not been fulfilled but is continuing with improvements, both in terms of context, input, process, and product aspects. For this reason, in this study, the author offers a model of academic supervision training based on KKS and KKG through mentoring.

Keywords: Evaluation; Academic Supervision Program; CIPP Model; Training; Mentoring
\end{abstract}




\begin{abstract}
Abstrak: Penelitian ini bertujuan untuk mengevaluasi program supervisi akademik kepala sekolah dasar negeri di Kabupaten Rejang Lebong, Indonesia. Penelitian ini merupakan studi evaluasi model CIPP dengan pendekatan kualitatif. Subyek penelitian ini adalah kepala sekolah dan guru SD Negeri di Kabupaten Rejang Lebong. Teknik pengumpulan data meliputi observasi, wawancara, dan dokumentasi, serta reduksi data, penyajian data, dan verifikasi. Hasil penelitian mengungkapkan bahwa, pertama, pengaturan program supervisi akademik kepala sekolab tidak memenubi kriteria. Masih banyak kekurangan, seperti kurangnya pemahaman kepala sekolah tentang pengertian supervisi akademik, yang menghambat mereka dalam menyusun perencanaan program dengan baik. Kedua, masukan program supervisi akademik belum sepenubnya mendukung program, masib banyak. kekurangan seperti tidak adanya dukungan stakeholder, dan belum dapat menemukan strategi yang tepat baik dalam perencanaan maupun dalam pelaksanaan program. Ketiga, proses program supervisi akademik belum sesuai dengan rencana, seperti langkah-langkah pelaksanaan program. Keempat, produk program supervisi akademik. belum menunjukean peningkatan kinerja guru. Namun, baik guru maupun kepala sekolah menginginkan agar program supervisi akademik. kepala sekolab tetap berjalan dengan membenabi segala kekurangan dan kelemahannya. Kesimpulan program supervisi akademik kepala sekolah SD Negeri di Kabupaten Rejang Lebong secara Keseluruban belum terpenubi tetapi terus dilakukan perbaikan, baik dari segi konteks, masukan, proses, maupun aspek produk. Untuk. itu, dalam penelitian ini penulis menawarkan model pelatiban supervisi akademik berbasis KKS dan KKG melalui pendampingan.

Kata Kunci: Evaluasi; Program Supervisi Akademik; Model CIPP; Pelatihan; Pendampingan
\end{abstract}

\title{
INTRODUCTION
}

The rapid development of science and technology demands the presence of quality Indonesian human resources, who are able to compete locally and globally. These quality human resources can only be obtained through education, especially through format education or schools. Not a few efforts by the Indonesian government in order to improve the quality of education such as improving the curriculum, laws and regulations including increasing the education budget. However, until now the problem of the quality of education is still a central issue, where the quality of Indonesian education has always been in the spotlight of the international community.

UNESCO data in the 2016 Global Educational Monitoring (GEM) Report states that the quality of education in Indonesia only ranks tenth out of fourteen developing countries. Meanwhile, the quality of teachers as an important component in education is of concern, namely at number fourteen out of fourteen developing countries in the world (Yunus, http://www.kumparan.com). While the World Bank determined that the human development index or human capital index (Human Capital Index) was rated 87th out of 157 nations evaluated in 2018 (http://www.antarnews.com). The 2019 Global Talent Competitive Index is an increase in country competitiveness data based on the country's human resource talent (HR) capabilities, one of which is Education, Indonesia is ranked sixth out of ten ASEAN countries 
(Scholastia Britya http://www.tirto.en). Based on the Educational Index issued by the Development Report in 2017, Indonesia is in the destination position as ASEAN. Another indicator of the quality of education in Indonesia can be seen from the results of the teacher competency test where the average national achievement is 56.37 (detik.com.2019) specifically for Rejang Lebong 2020, the UKG primary school results of 51.54 are still below the provincial average of 53.,74. While the minimum standard set by the government is 70.00 (Depdikbud). In addition, the dropout rate and not going to class are still quite high. Dropouts from public elementary schools in Rejang Lebong Regency in 2019 reached 109 people. While repeating or not going to class 505 people. Another problem is school accreditation at all levels and types, there are still schools that have not reached the minimum standard or have not been accredited. For basic education, junior high school is $7.3 \%$ and for elementary school $4.8 \%$, of course this is a reflection of how schools are managed.

Other indicator of the quality of education in Indonesia can be seen from the results of the teacher competency test where the average national achievement is 56.37 (detik.com.2019) specifically for Rejang Lebong 2020, the UKG primary school results of 51.54 are still below the provincial average of 53.,74. While the minimum standard set by the government is 70.00 (Depdikbud). In addition, the dropout rate and not going to class are still quite high. Dropouts from public elementary schools in Rejang Lebong Regency in 2019 reached 109 people. While repeating or not going to grade 505 people. Another problem is school accreditation at all levels and types, there are still schools that have not reached the minimum standard or have not been accredited. For basic education, junior high school is $7.3 \%$ and for elementary school $4.8 \%$, of course this is a reflection of how schools are managed.

The conditions as described above are influenced by many factors, including low physical facilities, low quality of teachers, low student achievement, low teacher welfare, high education costs, curriculum and school programs have not been running properly (Kemendikbud 2016:8). The most prominent problems in Rejang Lebong Regency are the problem of physical facilities and teacher quality problems, physical quality problems are shown from the classrooms, for elementary schools the heavily damaged classrooms are 92 rooms, moderately damaged are 97 rooms, the rest are 1218 in good condition and slightly damaged (PDSPK verification data November 2018). Meanwhile, the quality of teachers as measured by three indicators, namely qualified teachers, certified teachers and the student-to-teacher ratio are next: there are still $15 \%$ of teachers who have not qualified for D4/S1 and have not been certified, amounting to $43.3 \%$ (Directorate General of GTK November 2018). Besides that, teacher eligibility is not good enough because it is still below 
$90 \%$. The level of elementary school has only reached $77.25 \%$, meaning that there are still many elementary school teachers who are not graduates of $\mathrm{D} 4 / \mathrm{S} 1$, PGSD/PGMI.

From the description above, of course, schools as formal institutions must improve themselves to repair damaged facilities and infrastructure for the convenience of students learning. Of course, the role of local governments is very much needed, namely through the education budget where in 2018 only $10.15 \%$ of the APBD (NPD, 2018) is the most important of which is improving the quality of teachers. "Improving teacher competence as the spearhead of producing students who incidentally are the nation's successors is a necessity" (Intjen Kemendikbud, Kompas, 15 September 2018). Improving teacher competence can be done in many ways, both individually and in groups, for example following further education, attending upgrading/training (Work Shop) and being active in teacher professional organizations. However, not all teachers have the opportunity and take advantage of this, so what is being carried out is continuous guidance by the principal of the teachers in the school he leads, namely through an academic supervision program. The essence of academic supervision is a series of activities to assist teachers in developing their ability to manage the learning process to achieve teaching goals ( $\mathrm{K}$. Hoi and Forsyt, 1986), (ASCD, 1987), (Mulyadi and Fahriana, 2018), (Suhardan, 2010), (Sergiovanni, 1993), (Sagala, 2010), (Sahertian, 2010), (Ari Kunto, 2004). From this definition, it means that teachers need to be provided with assistance services by the person in charge of the school, namely the principal.

This is certainly in line with one of the principal's duties as a supervisor, meaning that the principal is responsible for carrying out his e-supervision through academic supervision. Glickman (1981) states that to be able to carry out supervision effectively, conceptual, interpersonal and technical skills are needed. Besides that, knowledge of techniques and models of supervision should be mastered and understood well; therefore every principal must have and master the concept of academic supervision which includes knowledge and concepts, objectives, functions and principles as well as the dimensions of the substance of academic supervision.

Many parties believe that if academic supervision is carried out properly, the quality of the student learning process and the quality of teaching teachers will be better (increase) and can avoid bad events that we often hear about, such as violence against students or better. Sahertian (2008) states that academic supervision that is able to improve the quality of teacher teaching is carried out based on objective data and facts. This means that academic supervision is not carried out because of dislike of the teacher or deliberately looking for mistakes. In line with that, several research results show that academic supervision 
programs carried out by supervisors or school principals have a significant influence on teacher performance in improving the quality of the learning process as illustrated by several research results. (Ratlin, 2017), (Prasetyono et al, 2018), (Denko and Wamena, 2014), (Ikebusi et al, 2016), (Ekpoh et al, 2015), (Tanaa et al, 2016), (Astuti and Dacholfany, 2016).

However, on the other hand, the academic supervision program carried out by school principals has so far been limited to carrying out their duties and authorities, but it has not become a need or request from teachers as it should be in accordance with the concept of educational supervision (Kemendikbud, 2013). This is reinforced by the results of research which states that the academic supervision program carried out by supervisors and principals has not been effective. As revealed from several studies such as: (Rahaba, 2015), (Damayanti, 2016), (Mintaji, 2015), (Haimah, 2018).

The principal's duties as supervisors include planning supervision programs for both managerial supervision and academic supervision, implementing programs according to plans and carrying out follow-up actions. In the preparation of academic supervision programs there are no standardized standards but at least the program contains: Background, legal basis, objectives, success indicators, targets, approaches and supervision techniques, scope of supervision, schedule for supervision implementation and instruments to be used. Meanwhile, the implementation really depends on the approach and technique used. In the implementation of academic supervision, the individual technique of observation and class visits is carried out in three stages, namely pre-observation, observation and post-observation. Furthermore, follow-up academic supervision includes: evaluation of the results of supervision, followup on the results of supervision, stabilization of the supervision instrument. For this purpose, this study aims to evaluate the academic supervision program of public elementary school principals in the Rejang Lebong Regency area.

\section{RESEARCH METHODS}

This research is a qualitative research with the type of evaluation research, and the evaluation model used is the CIPP model, namely context evaluation, input evaluation, process evaluation and product evaluation from Stufflebeam. The research subjects were the principals and teachers of public elementary schools (SD) in Rejang Lebong Regency. Given the size of the research area, which is 15 sub-districts, the researchers took schools in three sub-districts with the first reason being based on the recommendation of the authorized official, the two regional characteristics are almost the same, and the third is due to cost and time, besides that there are security reasons. While the determination of schools and research respondents using Snow Ball. Data 
collection techniques through observation, interviews and documentation, data analysis techniques using data reduction steps, data presentation and verification or conclusion drawing (Miles and Huberman, 1992) and to test the validity of the data using source triangulation.

\section{RESULTS AND DISCUSSION}

First, evaluating the context of the academic supervision program, it was obtained data that almost all school principals did not understand the objectives of the principal's academic supervision program so that most of them were less able to describe how the program beneficiaries, program needs, program resources, problems faced and program background and program environment. This also happens to teachers. Almost all teachers are able to explain the purpose of supervision, the benefits of supervision; the need for supervision programs, supervision program resources, supervision program problems, supervision program background and program environment, the explanation is still very minimal. The results of observation and scrutiny of documents show that most schools cannot show complete academic supervision program planning documents. There is only an academic supervision schedule, even though a program must at least contain the background, legal basis, objectives, indicators of supervision success, objectives, supervision approaches and techniques, the scope of supervision, supervision implementation schedule and the instruments used (Kemendikbud, 2019). Likewise, in the implementation of academic supervision as a result of observation and scrutiny of documents, most of what is done is group supervision in the form of meetings or meetings, class supervision is only carried out by a small number of principals, and even then they have not followed the actual class supervision steps. In other words, there is no initial meeting or post-supervision meeting, even though good academic supervision is supervision that is carried out individually by direct observation to the class with the following steps: pre-observation, observation and postobservation (Kemendikbud, 2019) and which even more worrying that the follow-up of supervision has not been carried out at all. The data was obtained either through interviews or based on observations and the results of examining documents.

Second, the evaluation of the input for the academic supervision program, the results showed that of the five input indicators for the academic supervision program, only coverage indicators were available, the rest were not available such as no stakeholder support at all, the principal's strategy in the academic supervision program was still very weak. It is said that because most of the principals have not mastered the techniques of supervision well, they do not even know the clinical supervision that is the reference for the Ministry of Education and Culture, the budget is not available, and there is no prior 
research before developing an academic supervision program, including a study on the results of supervision. academic year in the previous year. Whereas a good program must be supported by sufficient input so that the program can run well. Stufflebeam (2017) states that input evaluation is a precursor to the success or failure and efficiency of change efforts.

Third, evaluation of the academic supervision program process. Process evaluation includes ongoing checks of implementation and process documentation. In this section, the results of the study indicate that the academic supervision program, both in program planning and in program implementation and follow-up, has not been implemented properly. It is said that because in the preparation of program planning, the stages that should have been followed, namely determining the purpose of supervision, determining the supervision schedule, determining the technique and approach to supervision, and determining the supervision instrument. Likewise, the implementation has not followed the stages, namely starting from supervision of learning devices, then supervision of the learning process in the classroom and carrying out supervision of the assessment of learning outcomes, as well as the follow-up has not followed the stages that should be giving good feedback. Verbally or nonverbally, develop a follow-up plan, provide coaching or training if needed and finally report. Based on the observation and examination of documents, most of the principals are unable to show documentary evidence, both in the form of programs and instruments resulting from the implementation of supervision and follow-up plans. Most of them have not been well documented. Stufflebeam (2017) states that a good supervision program process is carried out from time to time, carried out according to the plan stated in the program, always monitored and there is clear good feedback.

Fourth, the evaluation of the product of the academic supervision program, this evaluation looks at the impact of the program, program effectiveness, program adaptability, program sustainability and adjustment, the research results show that for now the impact has not been seen, but both teachers and school principals have the same belief, the supervision program will have a very positive impact if the academic supervision program has been running well, the problem of the effectiveness of the principal's academic supervision program, research results also show that it is not effective. It is said that because of this academic supervision program, most schools have not been implemented as expected, both in program planning and program implementation and follow-up. And the rate of adaptation is very slow. For example, until now the adjustment to the curriculum from KTSP to K13 has not been fully implemented. The RPP has followed K13, but in its implementation in the field, most have not adjusted to the K13 pattern or 
model. Likewise, regarding the sustainability of the program, there is no framework for the stages to be carried out, so that its development is not visible at all. Likewise, about adjustment most school principals have not been able to adapt the appropriate supervision model that can be effective in their respective school environments. Sergiovanni (1993) states that the product of academic supervision is the development of professional abilities of teachers in understanding classroom life, developing teaching skills and using their abilities through certain techniques.

Based on the description above, it is clear that the principal's academic supervision program has not run as it should, in terms of context, input, process and product. This is of course many factors, including the lack of knowledge of the principal about the basic concept of educational supervision, especially academic supervision as a result of the assignment of teachers as principals who do not meet the requirements according to applicable regulations, where all teachers who receive these additional tasks (principals) have not have attended the education and training of prospective school principals which are requirements that must be met. Therefore, many improvements are needed in order to improve the principal's academic supervision program, one of which is through education and training. On this occasion the author offers "Training for Academic Supervision Programs Based on KKS and KKG for Mentoring".

\section{CONCLUSION}

Based on the results and discussion above, the results of this study can be concluded that first, the results of the context evaluation show that most of the principals do not understand the objectives, background and legal basis for the academic supervision program so that the utilization of existing resources has not been maximized, as well as environmental conditions both internal and external that are conducive have not been utilized as well as possible. The results of the evaluation of the input of the academic supervision program indicate that the fulfilment of the need to achieve the objectives of the academic supervision program has not been fulfilled, has not accommodated the interests of stakeholders, was not preceded by studies or research, there is no budget, the strategy is not clear, as well as the scope of supervision has not been well planned, The results of the three process evaluations show that implementation in the field, both in the program planning process, program implementation process and follow-up, almost all schools have not followed the existing academic supervision steps or guidelines issued by the Ministry of Education and Culture. Fourth, product evaluation, both the impact of effectiveness, adaptability, sustainability and adjustment. Its success in almost all schools has not been good through observations and existing documents. The factors causing the four problems mentioned above, one of which is the lack of 
knowledge obtained by principals about the basic concepts and practices of educational supervision, especially the concepts and practices of academic supervision because of the ten principals studied, none of them came from graduates of education and training for prospective principals. . Therefore, there is a need for supervision training for teachers and school principals and researchers offering a KKS and KKG-based academic supervision training model through mentoring.

\section{RECOGNITION}

Thanks to the honourable Rector of the University Prof. DR. Hazairin. $\mathrm{SH}$ and the management of the Bengkulu Semarak Foundation who have provided research data assistance through the research assistance program for advanced study lecturers.

\section{REFERENCES}

Arikunto, S. (2004). Dasar-Dasar Supervisi, Jakarta: Rineka Cipta.

Astutidan Dacholfany, (2016). Pengaruh supervise pengawasan sekolah dan kepemimpinan kepala sekolah terhadap kinerja guru SMP di kota Metro Lampung, JurnalLentera 1(2) 2004-2016.

Damayanti, (2016). Peningkatan mutu kinerja guru melalui supervise akadmik di SMK Negeri 1 Salatiga menghadapi PKG 2016, Jumal Pendidikan Imu Sosial, 26(1), 80-86.

Donkoh dan Dwamena, (2014). Effects of educational supervision on professional development: perception of public basic school teachers at Winneba, Ghana, British Journal Of Education, 2(6), 63-80.

Ekpoh, U. I., \&Eze, G. B. (2015). Principals' supervisory techniques and teachers' job performance in secondary schools in Ikom education zone, cross river state, Nigeria. British journal of education, 3(6), 31-40.

Gerintya, Scholastica, (2019). Index Pendidikan Indonesia rendah daya saing pun lemah, http://www.tirto.id

Glickman, C. D., Gordon, S. P., \& Ross-Gordon, J. M. (2001). Supervision and instructional leadership: A developmental approach. Allyn \& Bacon/Longman Publishing, a Pearson Education Company, 1760 Gould Street, Needham Heights, MA 02494. Web site: http://www. abacon. com.

Haimah, (2018). Academic supervision by school principals at state elementary school in Indonesia, Atlantis Press (295), 34-37.

Honig, M. I., \& Rainey, L. R. (2019). Supporting principal supervisors: what really matters? Journal of Educational Administration.

Ikebusi dkk, (2016). The impact of supervision of instruction on teacher effectiveness in scondary schools in nigeria, IJARET 3(3), 12-16. 
Itjen Kemendikbud, (2018). Peningkatan kompetensi guru, Jakarta: Kompas 15 September.

K.Hoy dan Forsyt, (1986). Effective Supervision theory Into Practice, Ann Arbor: Random House.

Kartini, D., Kristiawan, M., \& Fitria, H. (2020). The Influence of Principal's Leadership, Academic Supervision, and Professional Competence toward Teachers' Performance. International Journal of Progressive Sciences and Technologies, 20(1), 156-164.

Kemendikbud, (2018). Neraca Pendidikan daerah (NPD) Kabupaten Rejang Lebong tahun 2018, Jakarta: Kemendikbud.

Kemendikbud, (2018). Data ferivikasi PDSPK nopember 2018, Jakarta: Kemendikbud.

Kemendikbud, (2019). Supervisi penilaian kinerja guru (MPPKS-PKG, Jakarta: Dirjen GTK.

Masito, F., Risdianto, E., Oka, I. G. A. A. M., Daryanti, Y., \& Fathurrochman, I. (2021). Analysis of Online Learning System Needs Based on MOOCs. AL-ISHLAH: JurnalPendidikan, 13(2), 953-959.

Miles dan Huberman, (1992). Analisis data kualitatif, Jakarta: Universitas Indonesia.

Mulyadi dan Fahriana, (2018). Supervisi akademik, Malang: Madani.

Prasetyonodkk, (2018). Academic supervision toward teachers performance through motivation as intervening variable, Edulearn 12(2).

Prasetyono, H., Abdillah, A., \&Fitria, D. (2018).Academic supervision toward teacher's performance through motivation as intervening variable. Journal of Education and Learning (EduLearn), 12(2), 188-197.

Rahabav (2016). The effectiveness of academik supervision for teachers. Journal Of EduationIn Practic, 7(9), 47-55.

Ratlin, (2017). Pengaruh kualitas supervise akademik pengawas sekolah terhadap kinerja guru sains SMA Negeri di kota Bau-Bau.

Rusdiana, A., Huda, N., Mu'in, A., \&Kodir, A. (2020). The effectiveness of educational supervision in increasing the teacher's professional competence in the COVID-19 pandemic period. International Journal of Innovation, Creativity and Change, 14(5), 918-942.

Sagala, Syaiful, (2010). Supervisi Pembelajaran, Bandung: Alfabeta.

Sahertian, A. Piet, (2010). Konsep dasar dan teknik Supervisi pendidikan, Jakarta: Rineka Cipta.

Sahertian, A. Piet (2008). Supervisi Pendidikan dalam rangka pengembangan sumber daya manusia, Jakarta Rineka Cipta.

Sergiovannithomas,R. Sttarrat, (1993), Supervision a redefinition, Newyork: McGraw Hill. 
Shah, S. Z. H., Fathurrochman, I., Ayub, A., Altamirano, G. C., Rizwan, A., Núñez, R. A. S., Sabir, Z \& Yeskindirova, M. (2021). Inclined magnetized and energy transportation aspect of infinite shear rate viscosity model of Carreaunanofluid with multiple features over wedge geometry. Heat Transfer. https://doi.org/10.1002/htj.22367

Stufflebeam, Daniel L, (2017), The CIPP evaluation model, New York: The Guilford Press

Suhardan, Dadang, (2010). Supervisi profesional, Bandung Alfabeta.

Tanama, YJ, (2016). Imlementasi supervise klinis dalam meningkatkan profesionalisme guru 1(11), 2231-2235.

Tari, Dwi Nicken, 2018. Bank Dunia: IPM di peringkat 87, Indonesia agar teruskan investasi

SDM http://www.bisnis.com/user/486/dwi.nicken.tari.

Usman, Y. D. (2015). The Impact of Instructional Supervision on Academic Performance of Secondary School Students in Nasarawa State, Nigeria.Journal of Education and Practice, 6(10), 160-167.

Widianingsih, Mia, Kualitas pendidikan Indonesia, http://news.kompasiana.com.

Yunus, syarifudin, 2017. Mengkritisi kompetensi guru, http:// news.detik.com. 
184 |Tadbir : Jurnal Studi Manajemen Pendidikan, Vol. 5, No. 2, 2021

This page belongs to the Tadbir : Jurnal Studi Manajemen Pendidikan

TADBIR : Jurnal Studi Manajemen Pendidikan Vol. 5, No.2, November 2021

IAIN Curup - Bengkulu | p-ISSN 2580-3581; e-ISSN 2580-5037 